\title{
The effect of cathodic current density on the protective properties and cracking tendency in $\mathrm{Co}-\mathrm{Cr}-\mathrm{W}$ coatings
}

\section{V.V. Kuznetsov, ${ }^{1}$ A.V. Telezhkina, ${ }^{1}$ S.S. Kruglikov, ${ }^{1}$ V.A. Kolesnikov, ${ }^{1}$ O.A. Balabanova, ${ }^{1}$ V.V. Dushik ${ }^{2}$ and T.V. Rybkina ${ }^{2}$}

${ }^{1}$ Dmitry Mendeleev University of Chemical Technology of Russia, Miusskaya sq., 9 , 125047 Moscow, Russian Federation

${ }^{2}$ A.N. Frumkin Institute of Physical Chemistry and Electrochemistry, Russian Academy of Sciences, Leninsky pr. 31, 119071 Moscow, Russian Federation

E-mail:v.dushik@gmail.com

\begin{abstract}
The paper shows that a change in the cathodic current density has a significant impact on the cracking tendency, through porosity and protective properties of coatings. As the cathodic current density increases, the ability to cover in cracks formed at the early stages of the process decreases during further electrolysis. It was established that the coating under investigation exhibits the best physico-mechanical characteristics when tungsten content is the highest. Moreover, in this case, we should expect an improvement in the corrosion properties. The highest hardness value is observed when tungsten content is high. The porosity of the coatings, determined by standard filter paper method, decreases when heat treatment is carried out for 2 hours at $200^{\circ} \mathrm{C}$ in air. It is shown that a change in current density within the range of $0.15-0.45 \mathrm{~A} / \mathrm{cm}^{2}$ does not have a significant effect on the composition and hardness of the coatings. Long-term corrosion tests of the investigated $\mathrm{Co}-\mathrm{Cr}-\mathrm{W}$ coatings in simulated physiological medium (Hank's solution) were carried out. Mass and deep corrosion indicators/readings and corrosion severity/resistance scores were calculated gravimetrically. The corrosion behaviour in Hank's solution in the area of anodic potentials was studied. It is shown that the coating under investigation has an extended passive region/area, up to a potential of $1.2 \mathrm{~V}$ relative to a standard hydrogen electrode. The total/complete passivation current on the potentiodynamic polarization curve did not exceed $0.1 \mathrm{~mA} / \mathrm{cm}^{2}$. The dissolution of the alloy, accompanied by the appearance of a yellow colour, occurred only at positive potentials exceeding $\sim 1.3 \mathrm{~V}$. This coating has a higher corrosion resistance in biological and chloride-containing media, compared to chromium coatings not (doped) with other metals (Ni, Co, Mo, W) or non-metals (P, B, C).
\end{abstract}

Keywords: corrosion inhibition, cobalt-chromium-tungsten alloy, stellite, hardness, current density, coatings composition, electroplating, corrosion in physiological media. 


\section{Introduction}

The problem of inhibiting the corrosion of metallic construction materials, such as copper and iron alloys, is currently being successfully solved using corrosion inhibitors designed for various media and materials [1-5]. The inhibitory effect of the inhibitors is usually associated with the deceleration of electrode reactions due to the shift of the redox potential of the system [1], or due to the formation on the metal surface of nano-sized protective layers that isolate the protected metal from the corrosive environment [2-5].The latter principle is the most universal one for the protection of a wide range of materials since the shielding effect of the inhibitor is largely insensitive to the electrochemistry of metal corrosion dissolution. Unfortunately, the effect of such layers may be limited in time and often requires the permanent presence of an inhibitor in the solution to maintain the layers integrity. This can be avoided by the aimed formation of a layer of sufficient thickness, which performs improved physical, mechanical and anti-corrosion properties.

In previous studies [6,7], it was shown that $\mathrm{Co}-\mathrm{Cr}-\mathrm{W}$ coatings, obtained by electrodeposition from the water-dimethylformamide (solution), have a high corrosion resistance [7-10], protective properties and hardness. However, in order to determine the area of its practical application, the effect of the process conditions on the alloy composition, as well as on the corrosion and physicomechanical properties of the coating should be investigated in more detail. This paper describes the effect of current density on the composition, hardness and corrosion resistance of $\mathrm{Co}-\mathrm{Cr}-\mathrm{W}$ coatings. The most effective electrodeposition conditions to produce coatings with improved corrosion and physicomechanical properties are determined.

\section{Experimental methods}

$\mathrm{Co}-\mathrm{Cr}-\mathrm{W}$ coatings were besieged from an electrolyte of the following composition (mol/1): $\mathrm{CrCl}_{3}$ 1.0, $\mathrm{Na}_{2} \mathrm{WO}_{4}$ 0.05, $\mathrm{CoCl}_{2}$ 0.01-0.02, saccharin 0.5-2 g/l, water and dimethylformamide in a ratio of 1:1. The process of electrolysis was carried out at room temperature and in the absence of agitation, in a cell without separation of the cathode and anode portions (compartments) with an inert (insoluble) anode from platinized titanium $[6,7]$. Part of the experiments was carried out in the absence of saccharin. The performance (operating) range of the cathodic current density was chosen from 0.15 to $0.45 \mathrm{~A} / \mathrm{cm}^{2}$ since in trial experiments it was found that alloy deposition begins only at a current density of about $0.1 \mathrm{~A} / \mathrm{cm}^{2}$ and at a current density of $0.15 \mathrm{~A} / \mathrm{cm}^{2}$ current output does not exceed $2-4 \%$. The current density above $0.45 \mathrm{~A} / \mathrm{cm}^{2}$ dramatically increases the cracking tendency. Coatings were deposited on copper samples of $1 \mathrm{~cm}^{2}$.Some of the coated samples were heat treated in air at $200^{\circ} \mathrm{C}$ in a laboratory electric furnace SNOL-3/11-I2 for 2 hours. The composition of the coatings and the surface morphology were determined by X-ray fluorescence analysis using a Hitachi TM3000 scanning electron microscope (Japan) with an X-ray microanalyzer. Photos were taken at 1000x magnification. The hardness of coatings under consideration was measured in 
correspondence with Vickers hardness test with a PMT-3 M microhardness tester by the indentation of a diamond pyramidal tip with an apex angle of $136^{\circ}$ and a tip at the apex of a radius of no more than $0.5 \mu \mathrm{m}$. The applied load was changed within 2-200 g.

The loading time was $7 \mathrm{sec}$. Based on the microscopic examination of the samples after the load removal, the linear dimensions of the diagonal in the resulting dent were determined by the formula:

$$
H_{\mu}=18.54\left(L / C^{2}\right),
$$

where $H_{\mu}-$ microhardness value [GPa];

$L-$ load [g];

$C$-dent diagonal $[\mu \mathrm{m}]$.

The porosity of the obtained coatings deposited on samples of mild steel $(0.2$ at.\% C) with a surface of $4 \mathrm{~cm}^{2}$ was determined by the standard filter paper method. Filter paper impregnated with a solution containing $3 \mathrm{~g} / 1 \mathrm{~K}_{3}\left[\mathrm{Fe}(\mathrm{CN})_{6}\right]$ and $20 \mathrm{~g} / 1 \mathrm{NaCl}$ was applied to the sample surface for 5 minutes. The presence of through pores in the coating was determined by the appearance of blue dots on the filter paper. Based on the results obtained, the porosity of the coatings under investigation was estimated visually. We counted the number of blue dots on paper with pore marks and determined their average number using the formula:

$$
N_{\text {av }}=N_{\text {tot }} / S,
$$

where $N_{\text {tot }}$-total amount of pores on the test surface;

$S$-test surface area, $\left[\mathrm{cm}^{2}\right]$.

Corrosion behaviour in the anodic region/area was investigated using IPC-Pro digital potentiostat at a potential scan rate of $0.167 \mathrm{mV} / \mathrm{s}$ in an argon atmosphere of high purity in a simulated physiological medium (Hank's solution).A $1-\mathrm{cm}^{2}$ glassy carbon sample coated with a $\mathrm{Co}-\mathrm{Cr}-\mathrm{W}$ alloy was used as a working electrode, a silver chloride electrode was used as a reference electrode, and platinized titanium was used as counter electrode.

Corrosion rates and corrosion severity were evaluated by means of long-term corrosion tests. Glass-carbon samples with a deposited coating were kept in Hank's solution for a week, corrosion rates were calculated gravimetrically from the weight loss using the following formulas:

$$
\text { Mass: } K=\Delta m /(\tau \times s)\left[\mathrm{g} / \mathrm{h} \times \mathrm{m}^{2}\right] \text {; }
$$

where $\Delta m$ is the weight loss during the corrosion process $(\mathrm{g}), \tau$ is the time of the corrosion process, in this case, 168 hours, $s$ is the coated sample area $\mathrm{m}^{2}$.

$$
\text { Depth: }[\mathrm{mm} / \text { year }] P=(K / \rho) \times 8.76 \text {; }
$$

where $\rho$ is the coating density. 


\section{Results and discussion}

Data on the coatings' composition are given in Table 1. They show that the composition of the resulting alloy varies widely, and in all cases, the tungsten content does not exceed $2-4 \%$. However, it is not possible to trace any clear relationship between the composition of the deposited alloy and the cathodic current density in the investigated range. The coatings deposited from the saccharin-containing electrolyte were smoother, shinier and had a more decorative appearance than the coatings obtained without saccharin. However, the presence of saccharin did not prevent cracking of the coatings, which was particularly pronounced at an increased current density.

Table 1. The composition of the investigated $\mathrm{Co}-\mathrm{Cr}-\mathrm{W}$ coatings with a working current density of $0.15-0.45 \mathrm{~A} / \mathrm{cm}^{2}$.

\begin{tabular}{|c|c|c|c|c|c|c|c|c|}
\hline \multirow{2}{*}{$i, \mathrm{~A} / \mathrm{cm}$} & \multicolumn{6}{|c|}{ Element, \% } & \multirow{2}{*}{$\begin{array}{c}\text { Heat } \\
\text { treatment }\end{array}$} & \multirow{2}{*}{$\begin{array}{c}\text { Saccharin } \\
0.5-2 \mathrm{~g} / 1\end{array}$} \\
\hline & C & $\mathbf{O}$ & $\mathbf{S}$ & Co & $\mathrm{Cr}$ & $\mathbf{W}$ & & \\
\hline 0.15 & 5.26 & 28.6 & - & 44.51 & 19.92 & 1.7 & - & - \\
\hline 0.25 & 6.69 & 14.52 & - & 50.58 & 25.29 & 2.85 & - & - \\
\hline 0.35 & 4.37 & 16.31 & - & 16.76 & 61.42 & 1.13 & - & - \\
\hline 0.45 & 4.99 & 13.35 & - & 49.49 & 29.5 & 2.66 & - & - \\
\hline 0.15 & 6.23 & 15.82 & 0.61 & 40.44 & 35.79 & 1.11 & - & + \\
\hline 0.25 & 6.13 & 16.54 & 0.87 & 29.04 & 46.27 & 1.16 & - & + \\
\hline 0.35 & 6.65 & 16.28 & 0.67 & 34.16 & 41.19 & 1.06 & - & + \\
\hline 0.45 & 6.46 & 14.3 & 0.51 & 42.34 & 35.18 & 1.2 & - & + \\
\hline 0.15 & 5.98 & 13.94 & - & 57.56 & 20.2 & 2.3 & + & - \\
\hline 0.25 & 5.83 & 12.49 & - & 56.33 & 22.79 & 2.56 & + & - \\
\hline 0.35 & 5.29 & 15.38 & - & 22.78 & 55.1 & 1.45 & + & - \\
\hline 0.45 & 5.27 & 13.61 & - & 33.2 & 46.27 & 1.64 & + & - \\
\hline 0.15 & 7.44 & 18.15 & 0.7 & 25.57 & 47.31 & 0.81 & + & + \\
\hline 0.25 & 7.79 & 18.02 & 0.74 & 27.85 & 44.5 & 1.06 & + & + \\
\hline 0.35 & 7.8 & 14.16 & 0.63 & 40.82 & 35.45 & 1.1 & + & + \\
\hline 0.45 & 6.9 & 14.77 & 0.54 & 36.39 & 40.37 & 1.01 & + & + \\
\hline
\end{tabular}

As can be seen from the data presented in Table 1, all obtained precipitates (coatings) contain 1-2.8\% tungsten. Its co-precipitation/co-deposition with cobalt is explained by the phenomenon of so-called induced co-precipitation of a refractory metal paired with an iron group metal [11], although in this work we could not find a clear dependence between the content of tungsten and cobalt in the coating. 
$\mathrm{X}$-Ray fluorescence analysis showed that carbon and oxygen are additionally included in the $\mathrm{Co}-\mathrm{Cr}-\mathrm{W}$ coating. The presence of carbon in the coating is characteristic of the electrodeposition of chromium and its alloys from electrolytes based on trivalent chromium compounds [12-15]. The source of carbon is apparently dimethylformamide. As shown in our earlier studies, oxygen presents in the coating in the form of chromium and tungsten oxides and chromium hydroxides. Cobalt, chromium and tungsten are present in the coating both at a depth of 10-20 nm and in the surface layers [6,7]. Sulphur inclusions are found only in samples obtained in a solution containing saccharin.

The presence of tungsten in the coating is an important factor determining the corrosion and physicomechanical properties of coatings. According to the literature [16], even a small amount of a refractory metal in the alloy (up to 1\%) can reduce the corrosion rate by tens of times. In our earlier works, it was also shown that small amounts of tungsten in the coating reduce the corrosion current by several orders of magnitude. $[8,9,13,14]$.

When measuring the microhardness of coatings (Figure 1), it was shown that the presence of saccharin in the electrolyte has a significant effect on the hardness of coatings, while heat treatment slightly increases it.

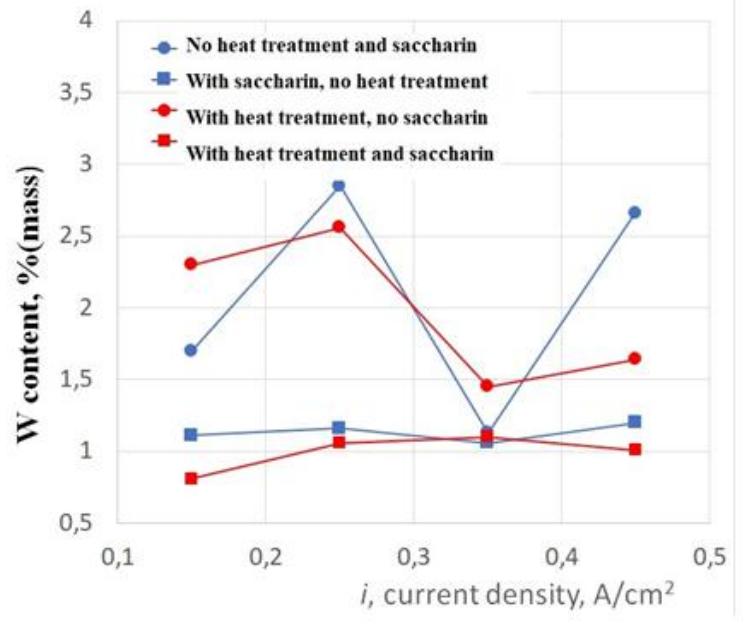

(a)

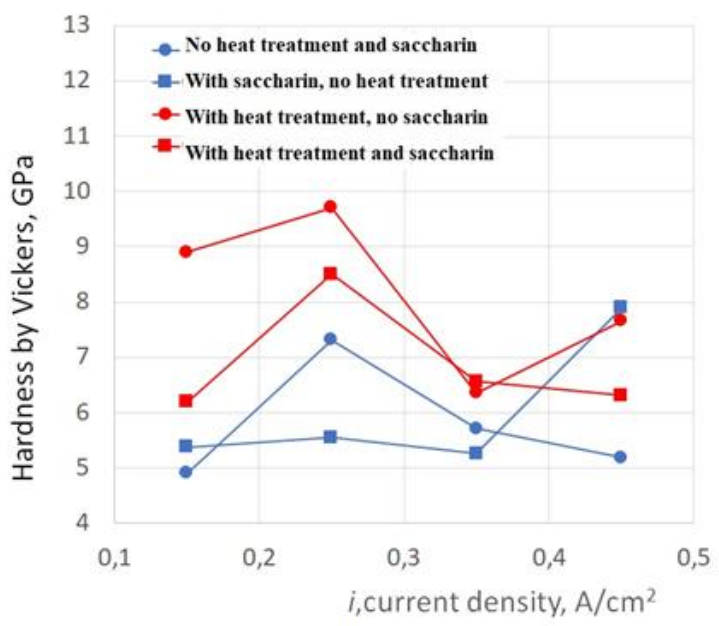

(b)

Figure 1. Dependence of tungsten content (a) and microhardness (b) in $\mathrm{Co}-\mathrm{Cr}-\mathrm{W}$ coatings on working/operating current density. a - W content, mass\%; $\mathrm{b}$ - Vickers hardness, GPa.

The porosity of the investigated coating plays an important role, since in the $\mathrm{Co}-\mathrm{Cr}-\mathrm{W} / \mathrm{steel}$ galvanic couple the alloy is the cathode with respect to the steel and, therefore, can protect the steel only if there are no uncoated areas and no pores. Therefore, to protect steel parts, it is essential to obtain a non-porous coating.

Samples for determining the porosity are deposited of the steel coating, both in the absence of saccharin, and from electrolytes containing saccharin in the amount of $0.5-2 \mathrm{~g} / 1$ at different current densities and different thickness. Porosity was determined 
visually, the results are presented in Table 2. Porosity was measured both in the heattreated samples and in the samples that were not subjected to heat treatment.

Table 2. Effect of current density on the porosity of the studied $\mathrm{Co}-\mathrm{Cr}-\mathrm{W}$ coatings.

\begin{tabular}{|c|c|c|c|}
\hline $\begin{array}{l}\text { Current density, } \\
\qquad \mathbf{A} / \mathbf{c m}^{2}\end{array}$ & $\begin{array}{c}\text { Saccharin } \\
0.5-2 \mathrm{~g} / 1\end{array}$ & $\begin{array}{c}\text { Heat } \\
\text { treatment }\end{array}$ & $\begin{array}{c}\text { Porosity, } \\
\text { pore amount } / \mathrm{cm}^{2}\end{array}$ \\
\hline 0.15 & - & - & 4 at the edges \\
\hline 0.25 & - & - & 3 at the edges \\
\hline 0.35 & - & - & 1 at the edges \\
\hline 0.45 & - & - & 1 at the edges \\
\hline 0.15 & + & - & No visible ones \\
\hline 0.25 & + & - & 5 at the edges and in the centre \\
\hline 0.35 & + & - & 1 closer to the centre \\
\hline 0.45 & + & - & 4 at the edges \\
\hline 0.15 & - & + & No visible ones \\
\hline 0.25 & - & + & 2 at the edges \\
\hline 0.35 & - & + & 4 at the edges and in the centre \\
\hline 0.45 & - & + & 5 at the edges and in the centre \\
\hline 0.15 & + & + & 3 at the edges \\
\hline 0.25 & + & + & 2 at the edges \\
\hline 0.35 & + & + & 5 all over the surface \\
\hline 0.45 & + & + & 2 all over the surface \\
\hline
\end{tabular}

The lowest porosity is noted in coatings deposited at $0.15 \mathrm{~A} / \mathrm{cm}^{2}$ from an electrolyte that does not contain saccharin, after heat treatment at $200^{\circ} \mathrm{C}$ for 2 hours in air atmosphere (Figure 2).

Studies of the coatings' morphology showed that the coating has a globular structure. With increasing current density, the space between the globules is filled with metal, the globules merge and a network of microscopic cracks forms (Figure 2), whose width increases after heat treatment of the coated samples (Figure 3). The surface of the coatings becomes smoother with the introduction of saccharin in the electrolyte in the amount of 0.5-2 g/l, and the roughness decreases slightly. It should be noted that the cracks (Figure 4) appear to be formed at the early stages of the electrodeposition process of the alloy and subsequently partially filled with metal; therefore, measurements of the porosity of the coatings do not trace the cracks as the through ones and their presence does not manifest itself in increasing the porosity of the coating. 


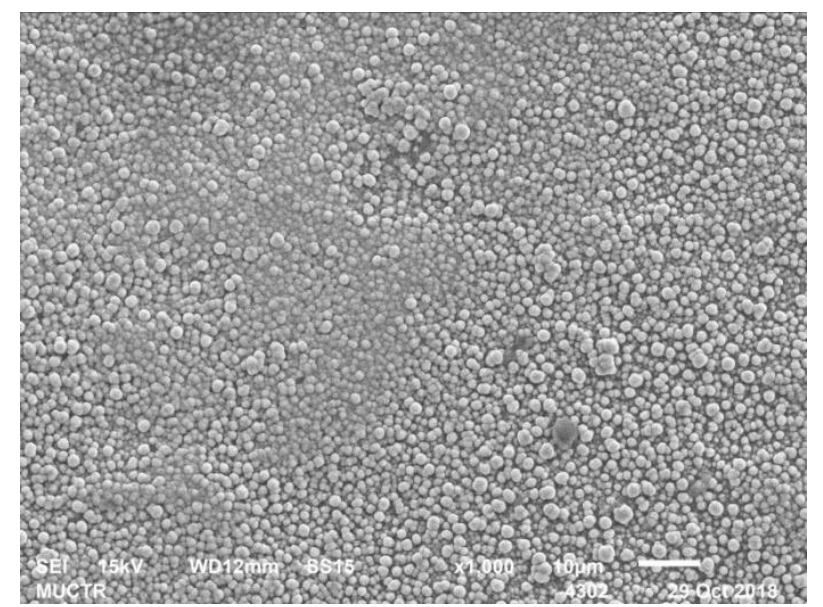

Figure 2. $\mathrm{Co}-\mathrm{Cr}-\mathrm{W}$ coating deposited at a current density of $0.15 \mathrm{~A} / \mathrm{cm}^{2}$ without saccharin and heat treatment.

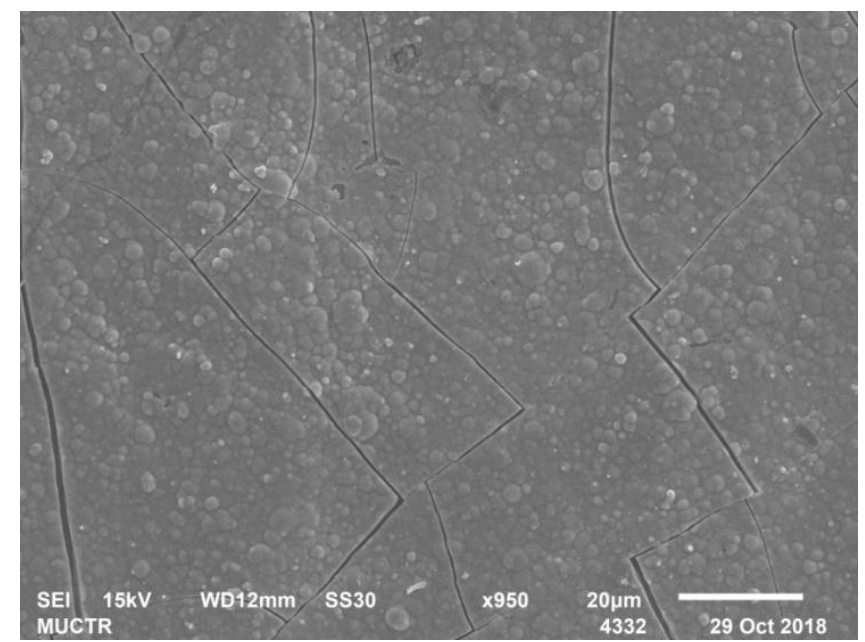

Figure 3. $\mathrm{Co}-\mathrm{Cr}-\mathrm{W}$ coating deposited at a current density of $0.35 \mathrm{~A} / \mathrm{cm}^{2}$ from an electrolyte containing saccharin without heat treatment.

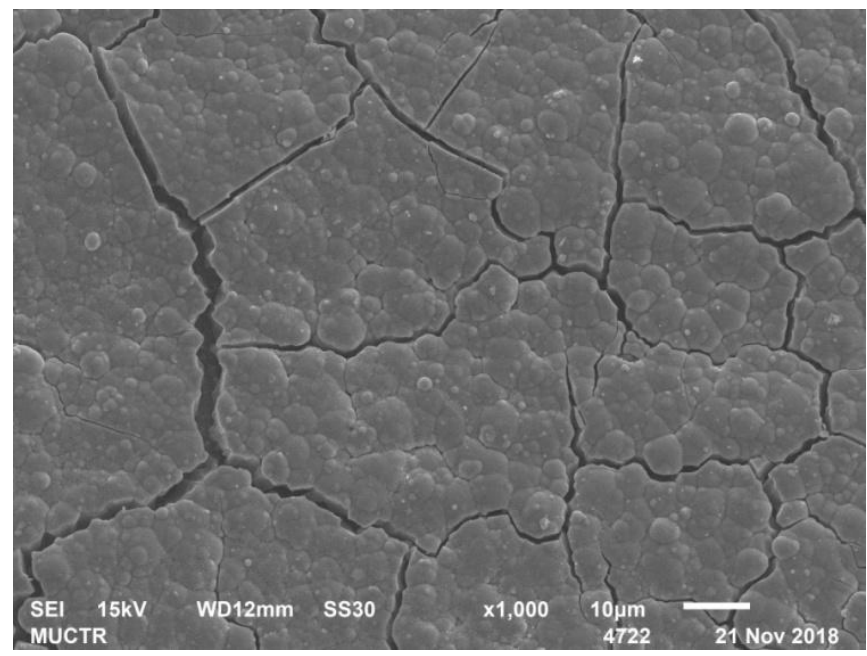

Figure 4. $\mathrm{Co}-\mathrm{Cr}-\mathrm{W}$ coating deposited at a current density of $0.35 \mathrm{~A} / \mathrm{cm}^{2}$ from an electrolyte containing no saccharin, followed by heat treatment. 
As the current density increases, the number of pores decreases, and the porosity is predominantly present at the edges. With an increase in the coating thickness, the porosity decreases, which was also noted in previous studies, where it was shown that the porosity reaches a constant value with a coating thickness of $2 \mu \mathrm{m}$ and above.

Figure 5 shows the corrosive behaviour in the anodic area in Hank's solution. The composition is given in [18]. The coating under investigation has a lengthy region of the passive state, up to a potential of $1.2 \mathrm{~V}$ relative to the standard hydrogen electrode. The total passivation current on the potentiodynamic polarization curve did not exceed $0.1 \mathrm{~mA} / \mathrm{cm}^{2}$. The alloy dissolution, accompanied by the appearance of a yellow colour, occurred only at positive potentials higher than $\sim 1.3 \mathrm{~V}$. These results indicate a fairly good corrosion resistance of coatings in the anodic area. At higher potentials, the dissolution of the coating and the release of yellow hexavalent chromium compounds into the corrosive environment were observed. There is a process of selective corrosion [19].

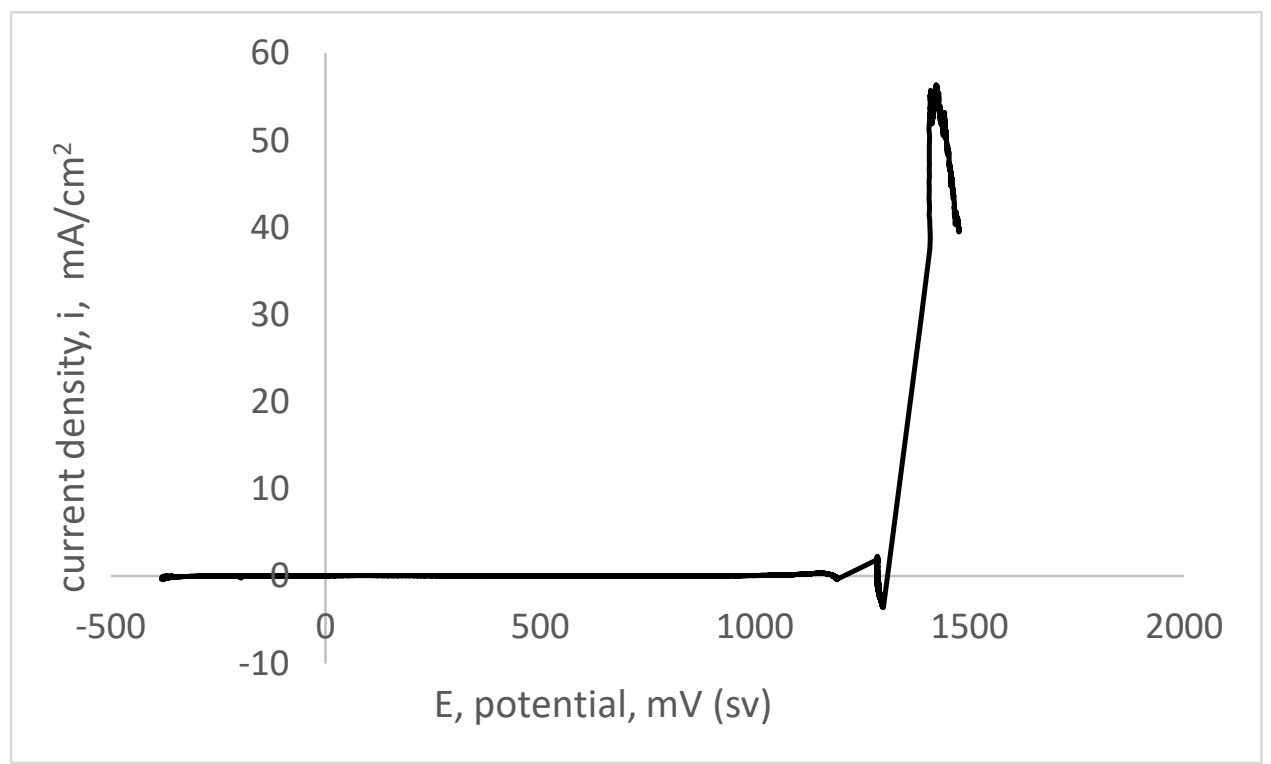

Figure 5. Anodic polarization curve of $\mathrm{Co}-\mathrm{Cr}-\mathrm{W}$ coating in simulated physiological medium.

Table 3 presents the results of gravimetric tests, i.e. indicators and corrosion severity. Based on the data in the table, it can be argued that the coating under investigation is very resistant in simulated physiological media containing chloride ions, unlike chromium coatings, which are unstable in this environment. This is due to the tungsten presence in the coating, the compounds of which form oxide films on the surface, hindering the development of the corrosion process. The coating is X-ray amorphous, which is a favourable factor when dealing with crevice and pitting corrosion.

The results obtained in this work show that $\mathrm{Co}-\mathrm{Cr}-\mathrm{W}$ coatings, possessing high hardness, wear resistance and resistance in chloride-containing media, cannot provide reliable protection of the steel base from corrosion due to their tendency to cracking and the formation of pores. Guaranteed corrosion protection can only be provided by the 
introduction of an additional underlayer (or a combination of intermediate layers) of metals or alloys that have sufficient ductility and do not form cracks, provided that the combination of these layers will ensure electrochemical protection of the lower layer by the upper/surface one. [20]

Table 3. Data on long-term corrosion tests, corrosion score/severity and indicators/readings calculated gravimetrically by weight loss during long-term corrosion tests.

\begin{tabular}{cccccccccc}
\hline $\boldsymbol{m}_{\mathbf{1}}, \mathbf{g}$ & $\boldsymbol{m}_{\mathbf{2}}, \mathbf{g}$ & $\mathbf{\Delta} \boldsymbol{m}, \mathbf{g}$ & $\boldsymbol{\tau}, \mathbf{h}$ & $\mathbf{S}, \mathbf{m}^{2}$ & $\begin{array}{c}\boldsymbol{K}, \\
\mathbf{g} /\left(\mathbf{m}^{\mathbf{2}} \cdot \mathbf{h}\right)\end{array}$ & $\mathbf{\rho}, \mathbf{g} / \mathbf{c m}^{\mathbf{3}}$ & $\boldsymbol{P}, \mathbf{m m} / \mathbf{y e a r}$ & $\begin{array}{c}\text { Corrosion } \\
\text { score/ } \\
\text { severity }\end{array}$ & $\begin{array}{c}\text { Coating } \\
\text { characteristics }\end{array}$ \\
\hline 0.21127 & 0.21122 & 0.00005 & 168 & 0.000222 & 0.001207 & 8.7 & 0.001215 & 2 & $\begin{array}{c}\text { Very/rather } \\
\text { stable/ } \\
\text { persistent }\end{array}$ \\
\hline
\end{tabular}

* $m_{1}-$ mass before corrosion; $m_{2}-$ mass after corrosion.

\section{Acknowledgments}

This study was financially supported by the Ministry of Education and Science of the Russian Federation (Agreement on grant no. 14.574.21.0169 of September 26, 2017, unique ID of the project RFMEFI57417X0169).

\section{References}

1. L.I. Antropov, E.M. Makushin and V.F. Panasenko, Ingibitory korrozii metallov (Metal Corrosion Inhibitors), Kiev, Tekhnika, 1981, 183 pp. (in Russian).

2. Yu.I. Kuznetsov, Kh.S. Shikhaliev, M.O. Agafonkina, N.P. Andreeva, A.M. Semiletov, A.A. Chirkunov, A.Yu. Potapov and V.E. Solov'ev, Formation of passivating layers by 1,2,4-triazole derivatives on copper in aqueous solutions, Russ. J. Phys. Chem. A, 2017, 19, no. 12, 2458-2465. doi: 10.1134/S0036024417120147

3. M.O. Agafonkina, A.M. Semiletov, Yu.I. Kuznetsov, N.P. Andreeva and A.A. Chirkunov, Adsorption of sodium oleyl sarcosinate on zinc and its passivating action in neutral aqueous solution, Prot. Met. Phys. Chem. Surf., 2018, 54, no. 7, 1284-1291. doi: 10.1134/S207020511807002X

4. A.A. Chirkunov, D.O. Chugunov, G.V. Red'kina and Yu.I. Kuznetsov, The Influence of Steel Surface Modifying with Zinc Complexes of Phosphonic Acids on the Efficiency of Its Passivation by Organic Inhibitors, Russ. J. Electrochem., 2019, 55, no. 2, 115-121. doi: 10.1134/S1023193519010026

5. A.A. Chirkunov, Yu.I. Kuznetsov, Kh.S. Shikhaliev, M.O. Agafonkina, N.P. Andreeva, L.P. Kazansky and A.Yu. Potapov, Adsorption of 5-alkyl-3-amino-1,2,4-triazoles from aqueous solutions and protection of copper from atmospheric corrosion, Corros. Sci., 2018, 144, 230-236. doi: 10.1016/j.corsci.2018.08.056 
6. V.V. Kuznetsov, A.V. Telezhkina, A.G. Demakov and R.S. Batalov, Elektroosazhdeniye korrozionnostoykogo tipa kobal't-khrom-vol'fram iz vodnodimetilformamidnogo elektrolita, Gal'vanotekhnika i obrabotka poverkhnosti, 2017, 25, no. 1, 16-22 (in Russian).

7. V.V. Kuznetsov, E.A. Filatova, A.V. Telezhkina and S.S. Kruglikov, Corrosion resistance of $\mathrm{Co}-\mathrm{Cr}-\mathrm{W}$ coatings obtained by electrodeposition, J. Solid State Electrochem., 2018, 22, no. 7, 2267-2276. doi: 10.1007/s10008-018-3929-8

8. V.V. Kuznetsov, L.N. Pavlov, E.G. Vinokurov, E.A. Filatova, and V.N. Kudryavtsev, Electrodeposition of chromium-tungsten alloy from organo-aqueous solutions containing dimethyl formamide, Russ. J. Electrochem., 2015, 52, no. 2, 174-179. doi: 10.1134/S102319351502010X

9. V.V. Kuznetsov, L.N. Pavlov, E.G. Vinokurov, E.A. Filatova and V.N. Kudryavtsev, Corrosion resistance of $\mathrm{Cr}-\mathrm{C}-\mathrm{W}$ alloys produced by electrodeposition, J. Solid State Electrochem., 2015, 19, no. 9, 2545-2553. doi: 10.1007/s10008-015-3007-4

10. V.V. Kuznetsov, L.N. Pavlov, E.A. Filatova and E.G. Vinokurov, Peculiarities of chromium electrodeposition from water - dimethylformamide solutions, J. Solid State Electrochem., 2018, 22, no. 1, 217-225. doi: 10.1007/s10008-017-3728-7

11. A.T. Vas'ko and S.K. Kovach, Elektrokhimiya tugoplavkikh metallov, Kiyev: Tekhnika, 1983, 160 pp. (in Russian).

12. N.A. Vetlugin and N.A. Polyakov, Influence of water-soluble monomers on the corrosion protection ability of chromium coatings obtained from $\mathrm{Cr}$ (III)-based solutions, Int. J. Corros. Scale Inhib., 2018, 7, no. 4, 570-581. doi: 10.17675/2305$\underline{\text { 6894-2018-7-4-6 }}$

13. V.V. Kuznetsov and D.V. Matveev, Electrodeposition of chromium-molybdenum alloy from electrolyte based on chromium(III) sulfate, Russ. J. Electrochem., 2008, 44, no. 6, 740-744. doi: 10.1134/S1023193508060153

14. V.V. Kuznetsov, M.A. Vorob'yeva, T.V. Pshenichkina and S.Ye. Lyashenko, Elektroosazhdeniye korrozionno-stoykogo tipa Ni-Cr-Mo iz rastvorov, soyedineniy soyedineniya Mo(III), Korroz.: mater., zashch. (Corrosion: materials, protection), 2013, no. 2, 41-45 (in Russian).

15. O.V. Safonova, L.N. Vykhodtseva, N.A. Polyakov, J.C. Swarbrick, M. Sikora, P. Glatzel and V.A. Safonov, Chemical composition and structural transformations of amorphous chromium coatings electrodeposited from $\mathrm{Cr}$ (III) electrolytes, Electrochim. Acta, 2010, 56, no. 1, 145-153. doi: 10.1016/j.electacta.2010.08.108

16. V.V.Losev and A.P. Pchel'nikov, Anodnoye rastvoreniye splavov v aktivnom sostoyanii, Itogi Nauki i Tekhniki, VINITI, Elektrokhimiya, 1979, 15, 62-131 (in Russian).

17. N.E. Nekrasova and S.S. Kruglikov, The on relation between corrosion resistance and electrophysical properties of oxide films on zirconium alloy, Prot. Met. Phys. Chem. Surf., 2011, 47, no. 6, 793-796. doi: 10.1134/S2070205111060141 
18. M. Metikos-Hukovic and R. Babic, Passivation and corrosion behaviours of cobalt and cobalt-chromium-molybdenum alloy, Corros. Sci., 2007, 49, 3570-3579. doi: 10.1016/j.corsci.2007.03.023

19. A.V. Telezhkina, V.V. Kuznetsov, M.M. Aminov and A.G. Demakov, Issledovanie korrozionnogo povedeniya pokrytiya splavom $\mathrm{Co}-\mathrm{Cr}-\mathrm{W} \mathrm{v}$ imitirovannykh fiziologicheskikh sredakh, Uspekhi v khimii i khimicheskoy tekhnologii, 2017, 31, no. 4, 34-36 (in Russian)

20. V.V. Kuznetsov, A.V. Telezhkina and S.S. Kruglikov, Zashchitnoye pokrytie dlya meditsinskikh instrumentov $i$ sposob ego naneseniya (Protective coating for medical tools and application method), RF Patent No. 2,674,694, A61L 31/00 (2006.01) C25D 3/06 (2006.01), published December 12, 2018 (in Russian). 